\title{
DDT in Fishes and Soils of Lakes from Brazilian Amazon: Case Study of Puruzinho Lake (Amazon, Brazil)
}

\author{
Giselle C. Saldanha, ${ }^{a, b}$ Wanderley R. Bastos, ${ }^{b}$ João Paulo M. Torres ${ }^{*, a}$ and Olaf Malm ${ }^{a}$ \\ ${ }^{a}$ Eduardo Penna Franca Radioisotope Laboratory, Federal University of Rio de Janeiro, Centro de \\ Ciências da Saúde, bloco G, Subsolo, sala 61, Ilha do Fundão, 21941-902 Rio de Janeiro-RJ, Brazil \\ ${ }^{b}$ Wolfgang C. Pfeiffer Environmental Biochemistry Laboratory, Federal University of Rondônia, \\ Rodovia BR-364, km 9,5 Sentido Acre, 78900-500 Porto Velho-RO, Brazil
}

\begin{abstract}
Foram quantificadas as concentrações de DDT em peixes e 20 pontos de solos ao longo do lago Puruzinho. A determinação dos poluentes consistiu em quatro etapas consecutivas: extração, "clean-up", fracionamento e injeção automática em cromatógrafo gasoso acoplado a um detector de captura de elétrons (CG-DCE). Em relação as amostras de peixes foram realizados os testes para avaliação da distribuição normal dos teores de compostos em peixes ou solos de Shapiro-Wilk (distribuição dos compostos) e o teste de Kruskal-Wallis para variáveis independentes (distribuição dos compostos entre os hábitos alimentares). Os resultados de $\sum$ DDT nos peixes (ng $\mathrm{g}^{-1}$ peso seco) variaram de 0,3 a 71,4. As concentrações de $\sum$ DDT nos solos das casas variaram de 2,0 a $55,4 \mathrm{ng} \mathrm{g}^{-1}$, enquanto que nos solos florestais foram obtidos valores entre 1,6 e 13,3 $\mathrm{ng} \mathrm{g}^{-1}$. Para o cálculo de normalidade dos compostos entre as amostras de solos foi utilizado o teste de ShapiroWilk ( $\mathrm{p}<0,001=$ para solos das casas e $\mathrm{p}<0,007=$ para os solos florestais). Posteriormente também foi aplicado o teste U de Mann-Whitney para comparação de distribuição dos compostos entre as amostras das casas e de floresta $(\mathrm{p}>0,290)$.
\end{abstract}

DDT concentrations had been quantified in fishes and at 20 points along the "Puruzinho" lake. The determination of pollutants in the samples consisted in four consecutive steps: extraction, clean-up, fractionation and automatic injection in high resolution gas chromatography coupled to an electron capture detector. The $\Sigma$ DDT results in fishes ( $\mathrm{ng} \mathrm{g}^{-1}$ dry weight) ranged from 0.3 to 71.4. The concentrations of $\sum$ DDT on house soils varied from 2.0 to $55.4 \mathrm{ng} . \mathrm{g}^{-1}$ while forest soils the obtained values were between $1.6 \mathrm{e} 13.3 \mathrm{ng} \mathrm{g}^{-1}$. The Shapiro-Wilk test showed that the distribution was not normal for both the results of the soil of the houses $(p<0.001)$ as well as for the forest soils $(\mathrm{p}<0.007)$. The $\mathrm{U}$ test of Mann-Whitney reveled that there were no significant difference between the results obtained for both houses and forest soils ( $p>0.290)$.

Keywords: DDT, metabolites, fishes, soils, Amazon

\section{Introduction}

Dichlorodiphenyltricloroethane (DDT), synthesized in 1874 , was the first of the synthetic insecticides when it was rediscovered in 1939 to be used as a mothproof agent in wool. Since them it was largely used both in agriculture and in disease vector control against malaria, yellow fever and leishmaniasis. The first one is considered to be the one of the main focal disease of the world. At the Amazon region it is classified as an endemic disease. ${ }^{1}$

\footnotetext{
*e-mail: jptorres@biof.ufrj.br
}

In 1965, the combat of malaria in Brazil was based on the creation of the campaign for the eradication of malaria (EMC), the Amazon applying a strategy based on intra application of DDT. However, the characteristics of the Amazon region, dominated by precarious housing, non regular wall surfaces that do not allows a proper and correct application of DDT, put under the risk of failure the conventional strategy, which then were confirmed. ${ }^{2}$

Around 1970 the use of DDT was banned at most of the developed world due to its toxicity, environmental persistence and insect resistance. ${ }^{3-5}$ The physic-chemical and biological properties of DDT and its main metabolites, 
as well as to the other organochlorine compounds make them to be readily absorbed by the organisms. The accumulation rate varies among the species and maybe related to the environmental concentration at a given time, to the overall conditions of the site as well as to the time trend of the exposure.

The aquatic biota is an important reservoir of DDT, its metabolites and other organochlorines compounds and is a consequence of the biomagnification process along the food chains. ${ }^{6}$ In animals the degradation of DDT follow mainly the dehydrochlorination step via DDE (dichlorodyphenildichloroethylene) formation, but it may also degraded to DDD (dichlorodyphenyldichloroethane) in a minor scale.?

Organochlorine residues have contaminated practically all of the ecosystems and they are often found in the most varied environmental matrices. Researchers recently found the organic pollutants moving through the atmosphere from its sources located in warmer areas of the globe and showed that they may condense when the air masses reach the colder regions, leading the pollutant to precipitation over soils, vegetation and water courses. ${ }^{8}$

The transport of DDT through the soils systems may also occur by colloidal transportation, via solvents and by biosorption. However the mobility of DDT is somewhat low due to its lack of solubility in water and high affinity to clay and silt and other mineral surfaces, especially when covered by organic matter films. ${ }^{9}$

In the tropics the permanence of DDT is expected to be shorter, rendering to high evaporating and degradation rates by microorganisms. DDT can disappear more rapidly during floods, but this escape also occurs in dry conditions. Soil type and $\mathrm{pH}$ seems to govern such phenomena, with acidic soils rendering a longer half life for tropical soils. In general, in temperate soils the half life is estimated to be greater than 5 years or more. ${ }^{10}$

\section{Experimental}

\section{Study area}

The "Puruzinho" Lake is located at "Humaitá" municipality in the utmost south region of the Amazonas State in Brazil (Figure 1). It is formed by the "Puruzinho" River watershed and it is located around $5 \mathrm{~km}$ from its mouth at the left margin of the "Madeira" River, one of the most important tributaries of the right margin of the Amazon River. The lake's area corresponds to $38 \mathrm{~km}^{2}$ and its perimeter was calculated in $23.195 \mathrm{~m}^{11}$

In the high water period (rainy season, DecemberMay), the majority of lakes and streams of the "Madeira"

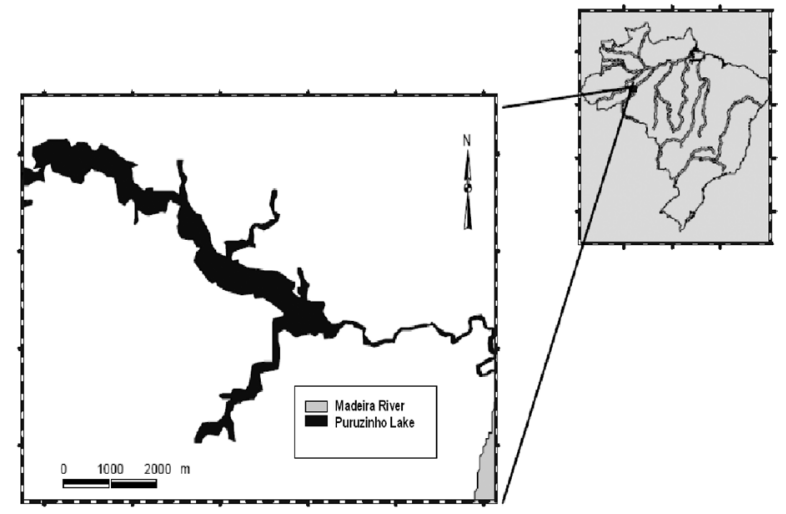

Figure 1. Study area: Puruzinho Lake, Humaitá-Amazon.

River basin has its levels influenced by the waters of the "Madeira" River, both directly (in places where the river invades the streams), as indirectly (where it prevents the disposal of surface water), forming temporary lakes. During the period of increased drought (dry season, AugustNovember), as the lakes "Puruzinho" remain attached to the "Madeira" River by a small channel, but it's water level decreases sharply compared to the period of high waters. This condition is typical in the Amazon.

The "Puruzinho" Lake was selected for this study basically because it gathers the following characteristics: (i) it represents a place with singular importance for environmental studies of the dynamics of persistent organic pollutants in particular DDT, due to its lacustrine conditions; (ii) the region has a historical spraying of DDT to control vectors and (iii) it is part of a larger study conducted by the team of the laboratory of Environmental Biogeochemistry in the analysis of breast milk showed the DDT. ${ }^{12}$

\section{Material and Methods}

The fish samples were collected at the "Puruzinho" Lake using fishing nets. The fishes were captures using $10 \mathrm{~m}$ long nets, with different sizes $(30,40,50,60,70$, $80,90,100$ and $120 \mathrm{~mm}$ ). In total were installed at every sampling point, three of this nets that were checked every four hours during $24 \mathrm{~h}$. The process of catching fish was approved by the department of fauna and fishing resources of the Brazilian institute of environment and natural resources (IBAMA-DIFAB) through the authorization No. 091.

The soils samples were collected at 20 points along the "Puruzinho" Lake shore line, all of them where georeferenced using GPS (Garmin 48). Half of the samples comprise soils under or around the older houses of the community. The other 10 samples where collect inside the forested areas that are located near these houses. All of 
the samples were from a "A" soil horizon layer and where collected using acetone rinsed metallic devices and where stored in acetone washed wide mouth glass jars closed with metal caps over an aluminum foil protection.

The determination of the persistent organic pollutants in both kind of samples followed the method described by Japenga and co-workers, ${ }^{13}$ modified by Torres. ${ }^{14}$ It consists of four distinct consecutive steps: extraction (modified continuous soxhlet for fishes samples and ultrasonic device for soils samples), clean-up (acid digestion of fat using sulfuric acid for fishes and desulphurization using sodium sulfite adsorbed to alkaline alumina for soils), fractionation (dry silica gel column) and automatic injection of $2 \mu \mathrm{L}$ (Shimadzu AOC-17, split less) high resolution gas chromatography coupled to an electron capture detector (Shimadzu GC-14B). All reagents used in this study were purchase from Merck (Pesticide Residue Analysis).

We used ultra-pure hydrogen $\left(35 \mathrm{~mL} \mathrm{~min}^{-1}\right)$ trough the SE-30/SE-52 capillary columns ( $25 \mathrm{~m}$; $0.2 \mathrm{~mm}$ i.d.; $0.25 \mu \mathrm{m}$ film thickness) and ultra-pure $\mathrm{N}_{2}$ was the make-up gas. The injector and the detector temperatures were set in 300 and $310^{\circ} \mathrm{C}$, respectively. For quantification, an internal standard OCN (octachloronaphtalene) was added prior injection.

\section{Statistical analysis}

To perform the basic descriptive analysis we used the software STATISTICA (version 6.0) and Microsoft Excel ${ }^{\circledR}$.

For the estimation of normal compounds distribution in soil samples from houses and jungles the Shapiro-Wilk test was performed. Later we also applied the U test of MannWhitney for comparison of distribution of compounds between the samples of houses and forest soils.

For fish samples we realized the test of Shapiro-Wilk normality to assess whether distribution of the compound was normal. In order to compare the distribution of compounds between diet was used the Kruskal-Wallis test for independent variables. The significance level $(\alpha)$ used was $5 \%$.

\section{Results and Discussion}

\section{Fish samples}

The work for the determination of the DDT and its metabolites concentration were realized in 86 specimens of 21 different fish species collected at the "Puruzinho" Lake in march of 2005 (Table 1). All of the analyzed samples presented residues of $\Sigma$ DDT below the maximum limits recommended by the US-FDA in 2002 (United States Food and Drug Administration: 5 mg kg-1 or ppm). ${ }^{15}$
Table 1. Fishes collected in "Puruzinho" Lake/AM, 2005

\begin{tabular}{|c|c|c|c|}
\hline Species & Vulgar name & Habit & $\mathrm{n}$ \\
\hline Acestrohynchus falsitrostis & Peixe Cachorro & Carnivorous & 01 \\
\hline Ageneiosus bevifilis & Mandubé & Carnivorous & 03 \\
\hline Bourengela maculata & Bicuda & Carnivorous & 08 \\
\hline Cichla monoculus & Tucunaré & Carnivorous & 01 \\
\hline Cichlasoma sp & Cará & Omnivorous & 01 \\
\hline Catoprion mento & Pacú Piranha & Omnivorous & 01 \\
\hline Geophagus sp & Acará & Omnivorous & 01 \\
\hline Hemiodus maculatos & Charuto & Herbivorous & 03 \\
\hline Hoplias Malabaricus & Traíra & Carnivorous & 08 \\
\hline Hydrolicus armatus & Pirandirá & Carnivorous & 01 \\
\hline Laemolita próxima & Piau & Herbivorous & 04 \\
\hline Mylossoma aureum & Pacu & Frugivorous & 03 \\
\hline Mylossoma duriventre & Pacu & Frugivorous & 04 \\
\hline Oxydoras sp & Bacu & Detritivorous & 04 \\
\hline Plagiosum sp & Pescada & Carnivorous & 01 \\
\hline Potamorihna altamazonica & Chora & Detritivorous & 10 \\
\hline Potamorihna latior & Chora & Detritivorous & 20 \\
\hline Psictogaser $s p$ & Branquinha & Detritivorous & 04 \\
\hline Schizodas fasciatum & Piau & Omnivorous & 03 \\
\hline Surubim lima & Bico de Pato & Carnivorous & 02 \\
\hline Triportheus flavus & Sardinha & Omnivorous & 03 \\
\hline Total & & & 86 \\
\hline
\end{tabular}

n: number of samples.

The basic descriptive analysis was performed between the compounds analyzed considering the different feeding habits (carnivorous, detritivorous, frugivorous, herbivorous and omnivorous) of the species examined. The results are shown in Table 2.

In the present work the minimum quantity of $\Sigma D D T$ (o,p'-DDT, $p, p$ '-DDT, $p, p$ '-DDD and $p, p^{\prime}$-DDE, $o, p^{\prime}$-DDE) detected by the used technique was $0.6 \mathrm{ng} \mathrm{g}^{-1}$ while the maximum one was $71.6 \mathrm{ng} \mathrm{g}^{-1}$. The results are quite similar to those found by D'Amato ${ }^{16}$ in fishes collected in 1991 (14.0 to $71.1 \mathrm{ng} \mathrm{g}^{-1}$ ) and higher to the ones collected in 2000 (6.5 to $\left.16.7 \mathrm{ng} \mathrm{g}^{-1}\right)$.

The Shapiro-Wilk test was performed and the value $\mathrm{p}<<0.01$ was found. To compare the effect of compound (quantitative variables) between different dietary habits (qualitative variables) all distributions were considered free, non-parametric.

The test used to compare independent variables was the Kruskal-Wallis test. The results were: no significant difference between eating habits for the $o, p^{\prime}$-DDT, $p, p^{\prime}$-DDT, $p, p^{\prime}$-DDD and $p, p$ '-DDE, where $0.75<\mathrm{p}<0.92$ and found a significant difference for the isomer $o, p$ '-DDE where $\mathrm{p}=0.045$. 
Table 2. Concentrations of DDT $\left(\mathrm{ng} \mathrm{g}^{-1}\right)$ and its metabolites in fish of different feeding habits of "Puruzinho" Lake-Amazon, 2005

\begin{tabular}{|c|c|c|c|c|}
\hline Compound & Mean & Min & $\operatorname{Max}$ & Std. deviation \\
\hline \multicolumn{5}{|c|}{ Carnivorous $\mathrm{n}=25$} \\
\hline o.p'-DDT & 0.59 & $<\mathrm{LOD}$ & 3.46 & 1.06 \\
\hline$p \cdot p^{\prime}$-DDT & 1.59 & $<$ LOD & 3.90 & 1.22 \\
\hline$o . p^{\prime}-\mathrm{DDD}$ & 0.00 & $<$ LOD & 2.83 & 0.91 \\
\hline$p \cdot p^{\prime}$-DDE & 0.61 & $<$ LOD & 3.11 & 1.01 \\
\hline o.p'-DDE & 2.34 & $<$ LOD & 9.92 & 2.60 \\
\hline \multicolumn{5}{|c|}{ Detritivorous $n=38$} \\
\hline o.p'-DDT & 0.85 & $<$ LOD & 4.98 & 1.46 \\
\hline$p \cdot p^{\prime}$-DDT & 1.58 & $<\mathrm{LOD}$ & 11.06 & 2.62 \\
\hline o.p'-DDD & 0.00 & $<\mathrm{LOD}$ & 8.31 & 1.53 \\
\hline$p \cdot p^{\prime}-\mathrm{DDE}$ & 1.27 & $<\mathrm{LOD}$ & 18.54 & 3.73 \\
\hline o.p'-DDE & 3.02 & $<$ LOD & 26.47 & 6.64 \\
\hline \multicolumn{5}{|c|}{ Frugivorous $n=07$} \\
\hline o.p'-DDT & 0.02 & $<$ LOD & 5.84 & 2.13 \\
\hline$p \cdot p^{\prime}$-DDT & 1.70 & $<\mathrm{LOD}$ & 24.50 & 8.85 \\
\hline o.p'-DDD & 0.00 & $<\mathrm{LOD}$ & 3.10 & 1.17 \\
\hline$p \cdot p^{\prime}-\mathrm{DDE}$ & 1.96 & $<\mathrm{LOD}$ & 27.36 & 9.52 \\
\hline o.p'-DDE & 3.43 & 1.39 & 13.66 & 4.32 \\
\hline \multicolumn{5}{|c|}{ Herbivorous $\mathrm{n}=07$} \\
\hline o.p'-DDT & 0.53 & $<$ LOD & 1.16 & 0.48 \\
\hline$p \cdot p^{\prime}-\mathrm{DDT}$ & 1.31 & $<$ LOD & 4.31 & 1.46 \\
\hline$o . p^{\prime}-\mathrm{DDD}$ & 0.00 & $<$ LOD & 1.97 & 0.91 \\
\hline$p \cdot p^{\prime}-\mathrm{DDE}$ & 0.75 & $<\mathrm{LOD}$ & 1.47 & 0.61 \\
\hline o.p'-DDE & 3.09 & $<$ LOD & 5.55 & 2.39 \\
\hline \multicolumn{5}{|c|}{ Omnivorous $\mathrm{n}=09$} \\
\hline o.p'-DDT & 0.18 & $<$ LOD & 3.84 & 1.23 \\
\hline$p \cdot p^{\prime}-\mathrm{DDT}$ & 0.70 & $<\mathrm{LOD}$ & 9.12 & 2.88 \\
\hline o.p'-DDD & 0.00 & $<$ LOD & 2.27 & 0.77 \\
\hline$p \cdot p^{\prime}-\mathrm{DDE}$ & 0.76 & $<\mathrm{LOD}$ & 6.98 & 2.34 \\
\hline o.p'-DDE & 1.66 & 0.98 & 22.47 & 6.90 \\
\hline
\end{tabular}

$<$ LOD: below the limit of detection of the method.

The ratio DDT/DDE found at the present work was 0.49 (mean) and demonstrated that the residues are old and the ratio is lowering. This trend is clearly observed when we compare the present results with the ones of D'Amato ${ }^{16} 1.53$ (1991) and 1.58 (2000) in fishes obtained at the local Market of "Humaitá"/Amazon, the municipality where the "Puruzinho" Lake belongs.

To observe the biomagnification phenomenon, where carnivorous fish with a diet had higher concentrations of DDT and its metabolites than those of non-carnivorous feeding habit, we also took the Kruskal-Wallis test for the values of $\sum$ DDT and was observed $\mathrm{p}=0.39$ which indicated that there was no significant difference between eating habits for the total DDT.
Among the fishes with predatory habits the highest concentration of $\sum$ DDT found was $14.1 \mathrm{ng} . \mathrm{g}^{-1}$ (Acestrorincus falcirostris - Urubarana), while the species that eat preferentially fruits (frugivorous) or detritus (detritivorous) presented maximum values of $71.4 \mathrm{ng} \mathrm{g}^{-1}$ and $50.7 \mathrm{ng} \mathrm{g}^{-1}$, respectively. The specie that presented the highest levels of $\Sigma$ DDT was Potamorihna latior $(\mathrm{n}=20)$.

\section{Soils samples}

The concentrations of $\Sigma$ DDT on house soils varied from 2.0 a $55.4 \mathrm{ng} \mathrm{g}^{-1}$ while forest soils the obtained values were between 1.6 and $13.3 \mathrm{ng} \mathrm{g}^{-1}$. The result of the descriptive analysis is shown on Table 3 .

Table 3. DDT and its metabolites concentrations $\left(\mathrm{ng} \mathrm{g}^{-1}\right)$ in house and forest soils of the "Puruzinho" Lake-Amazon, 2005

\begin{tabular}{|c|c|c|c|c|}
\hline & Average & Min & $\operatorname{Max}$ & Std. deviation \\
\hline & \multicolumn{4}{|c|}{ House soils $\mathrm{n}=10$} \\
\hline$o . p^{\prime}-\mathrm{DDE}$ & 7.48 & 0.85 & 31.02 & 9.56 \\
\hline$p \cdot p^{\prime}-\mathrm{DDE}$ & 1.01 & $<$ LOD & 6.23 & 1.96 \\
\hline$p \cdot p^{\prime}-\mathrm{DDD}$ & 6.96 & $<\mathrm{LOD}$ & 55.79 & 17.30 \\
\hline$o . p^{\prime}-\mathrm{DDT}$ & 7.26 & $<\mathrm{LOD}$ & 38.12 & 12.06 \\
\hline \multirow[t]{2}{*}{$p \cdot p^{\prime}$-DDT } & 8.39 & $<$ LOD & 70.80 & 22.04 \\
\hline & \multicolumn{4}{|c|}{ Forest soils $\mathrm{n}=10$} \\
\hline$o . p^{\prime}-\mathrm{DDE}$ & 3.09 & 0.71 & 7.18 & 1.75 \\
\hline$p \cdot p^{\prime}-\mathrm{DDE}$ & 0.70 & 0.02 & 2.19 & 0.84 \\
\hline$p \cdot p^{\prime}-\mathrm{DDD}$ & 0.47 & 0.22 & 0.81 & 0.20 \\
\hline$o . p^{\prime}-\mathrm{DDT}$ & 0.44 & $<$ LOD & 2.37 & 0.92 \\
\hline$p \cdot p^{\prime}$-DDT & 0.43 & $<$ LOD & 1.28 & 0.40 \\
\hline
\end{tabular}

$<$ LOD: below the limit of detection of the method.

First we performed the test of normality of ShapiroWilk, which sought to assess whether if the distribution of compounds (o, $p^{\prime}$-DDE, $p, p^{\prime}$-DDE, $p, p^{\prime}$-DDD, $o, p^{\prime}$-DDT and $p, p^{\prime}$-DDT) was normal between samples of soils. The Shapiro-Wilk test showed that the distribution was not normal for both the results of the soil of the houses $(p<0.001)$ as well as for the forest soils $(\mathrm{p}<0.007)$.

For comparison purposes the composite soil between the house and forest, all distributions were considered free, nonparametric. The test used to compare the samples was the $\mathrm{U}$ test Mann-Whitney. The results were: $\mathrm{p}>0.290$ compounds for $p, p^{\prime}$-DDE, $o, p^{\prime}-\mathrm{DDE}, p, p^{\prime}-\mathrm{DDD}$ and $p, p^{\prime}$-DDT and $\mathrm{p}<0.027$ for the $o, p^{\prime}$-DDT.

With the exception of the isomer $o, p^{\prime}$-DDT, there was no significant difference between the houses and compounds in the forest. This results may be explained the fact that $p, p$-DDT isomer correspond to $77.1 \%$ of the constitution of the insecticide. ${ }^{6,10}$ 
The $p, p^{\prime}-\mathrm{DDD} / p, p^{\prime}-\mathrm{DDE}$ ration in house soils $($ mean $=3.85)$ and for forest soils (mean $=1.87)$ were high when we compared this results to the previous work of Vieira ${ }^{17}$ at a location with a known history of DDT utilization. In this work, surface soils, from high areas located on the hills, were collected at rural areas of "Jacarepagua", located at Rio de Janeiro City were 0.06 (1997) and 0.09 (1999). On the one hand, this results were expected since our sampling occurred during the rainy season, with high index of heavy rains in this region. Our study confirms the previous work of Parr and Smith ${ }^{18}$ and Ramesh et al. ${ }^{19}$ that demonstrated that DDT degradation to DDD is mediated by anaerobic bacteria and fungus present in reductive environments, that may be the case of the Amazon soils during the rainy season. However, this interpretation must be taken with caution since no other soil parameters were measured in the present work. More work in this or in related areas should be done in the dry season to further investigate this degradation patterns and overall half life subjects.

The DDT/DDE ration can be used as an estimative of the time trend of DDT application. The present study of the "Puruzinho" Lake we have found mean ratios of 1.86 for the house soils and 0.85 for the forest soils. The mean value for the soil of the houses is similar to the one found by Vieira and co-workers, ${ }^{3} 1.91$ in 1997 and 1.19 in 1999. However these results are higher than the previous ratios reported by Torres,,${ }^{14}$ in a study using urban soils collected in some towns along the "Madeira" River. These high ratios may be due do recent reported uses of DDT against termites that commonly attack the local wooden houses.

\section{Conclusions}

The fishes that have a detritivorous habit presented the highest concentrations of $\sum$ DDT on its flesh when it was expected that the carnivorous ones would have more residues due to the biomagnification process.

Taken in account the fact that the highest concentrations were found on non-predatory detritivorous fish that are particularly eaten by the traditional riverine population, one question comes to our minds: at what point should we consider them at risk of being ill because of this pesticide? Does DDT represent a real menace to this people?

The DDT concentrations at both forest and house soils are irregularly distributed showing a somewhat erratic distribution and behavior of pesticide in the study area.

The efficacy of DDT on the malaria vector control in urban areas is unquestionable, since DDT was the synthetic molecule that had saved more lives along the last century. However, the study area is not urbanized and the huts were the people live, are not more that temporary housing made of wood and palm leaves. Thus, better housing may represent may be a better solution to improve their life quality and this may make a difference at such a place where people get malaria three times per year.

\section{Acknowledgments}

The authors are indebted to the Puruzinho Lake community. This work was supported by CNPq, CAPES, FAPERJ, ITREOH Fogarty-NIH/USA Grant No.: 1D43TW00640, MCT-CNPq-CT-Amazônia and CNPqPPG-7-Phase II. Special thanks to the field team of the UNIR-UFRJ agreement (PR-5 No.: 01-2002).

\section{References}

1. Barata, R. de C.; Cad. Saúde Pública 1995, 11, 128; http://www. scielo.br/pdf/csp/v11n1/v11n1a11.pdf, accessed in October 2009.

2. Loiola, C. C. P.; Silva M., C. J.; da Tauil, P. L.; Rev. Panam. Salud Publica; Pan. Am. J. Pub. Health 2002, 11, 235; http:// www.scielosp.org/pdf/rpsp/v11n4/10469.pdf, accessed in October 2009.

3. Vieira, E. D. R.; Torres, J. P. M.; Malm, O.; Environ. Res. 2001, $86,174$.

4. Carlson R.; Silent Spring, Houghton Mifflin Co.: New York, 2002.

5. Curtis, C. F.; Lines, J. D.; Paras. Today 2000, 16, 119.

6. WHO (World Health Organization), Environmental Health Criteria 83, Finland, 1989.

7. D’Amato C.; Torres, J. P. M.; Malm. O.; Quim. Nova 2002, 25, 995.

8. Simonich, S. L.; Hites, R. A.; Science 1995, 269, 1851.

9. Morrison, R.D.; Newell, A. E.; J. Soil Cont. 1999, 8, 63.

10. ATSDR, Toxicological, Profile for DDT, DDE and DDD, U.S. Department of Health and Human Services, Public Health Service 2002, 497; http://www.atsdr.cdc.gov/toxprofiles/tp35. pdf, accessed in October 2009.

11. Almeida, R. de; MSc Dissertation, Universidade Federal de Rondônia, Brazil, 2006.

12. Azeredo, A.; Sarcinelli, P.N.; Fonseca, M.F.; Saldanha, G.C.; Meire, R.O.; Rebelo, M.F.; Bastos, W.R.; Malm, O.; Luz, C.; Marowitz, S.; Chemosphere 2008, 73, S246.

13. Japenga, J.; Wagenaar, W. J.; Smedes, F.; Salomons, W.; Environ. Tech. Lett. 1987, 8, 9.

14. Torres, J. P. M.; Malm, O.; Vieira, E. D. R.; Japenga, J.; Koopmans, G.; Ciência e Cultura 1999, 51,54.

15. FDA (Food andDrug Administration), http://www.fda.gov/ICECI/ ComplianceManuals/CompliancePolicyGuidanceManual/ ucm123236.htm, accessed in January 2002. 
16. D’Amato, C.; Torres, J. P. M.; Malm, O.; Oecologia Brasiliensis 2007, 11, 202; http://www.oecologiaaustralis.org/ojs/index.php/ oa/article/view/179/105, accessed in October 2009.

17. Vieira, E. D. R.; Torres, J. P. M.; Malm, O.; Environ. Res. 2000, 86,174 .
18. Parr, J.F.; Smith, S.; Soil Sci. 1974, 118, 45.

19. Ramesh A.; Tanabe, S.; Tatsukawa, R.; Environ. Pollut. 1989, 62, 213.

Received: February 16, 2009

Web Release Date: November 26, 2009 